\title{
IDENTIFIKASI Staphylococcus aureus PADA DAGING AYAM YANG DIJUAL DI PASAR BESAR KOTA PALANGKA RAYA
}

\section{Identification of Staphylococcus aureus of Chicken in Pasar Besar of Palangka Raya City}

\author{
1*Rahmawati, ${ }^{2}$ Eva Apriliana, \& 2 Agus \\ ${ }^{1}$ Department of Biology Education, Universitas Palangka Raya, Jl. Kampus Tunjung Nyaho, Palangka Raya, Indonesia \\ ${ }^{2}$ Department of Medical Laboratory Technology, Universitas Muhammadiyah Palangkaraya, Jl. RTA. Milono Km. 1,5, Palangka Raya, \\ Indonesia \\ *e-mail : rahmawati@gmail.com
}

\begin{abstract}
ABSTRAK
Staphylococcus aureus dapat menjadi penyebab keracunan makanan pada manusia. Jenis bakteri ini dapat memproduksi enterotoksin yang menyebabkan pangan tercemar dan mengakibatkan keracunan pada manusia. Toksin yang dihasilkan bersifat tahan dalam suhu tinggi, meskipun bakteri mati dengan pemanasan namun toksin yang dihasilkan tidak akan rusak dan masih dapat bertahan meskipun dengan pendinginan ataupun pembekuan. Bakteri Staphylococcus aureus sering ditemukan pada bahan makanan yang berprotein tinggi seperti produk-produk telur dan daging ayam. Tujuan penelitian ini untuk mengetahui gambaran kontaminasi bakteri Staphylococcus aureus pada daging ayam yang dijual di Pasar Besar Kota Palangka Raya Tahun 2018. Pemeriksaan menggunakan media MSA (Manitol Salt Agar) karena media MSA merupakan media selektif diferenssial untuk membedakan Staphylococcus aureus dengan Staphylococcus epidermidis. Hasil dari pemeriksaan daging ayam di Pasar Besar Kota Palangka Raya 20\% positif tercemar bakteri Staphylococcus aureus pada sampel hari pertama. Sedangkan pada sampel hari kedua 13,3\% positif tercemar bakteri Staphylococcus aureus.
\end{abstract}

Kata Kunci : Staphylococcus aureus, keracunan , daging ayam

\section{ABSTRACT}

Staphylococcus aureus can be a cause of food poisoning in humans. This type of bacteria can produce enterotoxins that cause contaminated food and poisoning in humans. The toxin produced is resistant in high temperatures, although the bacteria die by heating but the resulting toxin will not be damaged and can still change despite freezing or freezing. Staphylococcus aureus is commonly found in high-protein foods such as egg and chicken products. The purpose of this study was to investigate the contamination of Staphylococcus aureus bacteria in chicken meat sold in Pasar Besar Kota Palangka Raya in 2018. The examination using MSA media (Manitol Salt Agar) because MSA media is different selective media to differentiate Staphylococcus aureus with Staphylococcus epidermidis. The results of examination of chicken meat in Pasar Besar Kota Palangka Raya $20 \%$ positive contaminated Staphylococcus aureus bacteria in the first day sample. In the second day sample found $13.3 \%$ positive contaminated Staphylococcus aureus bacteria.

Keywords: Staphylococcus aureus, poisoning, chicken

\section{PENDAHULUAN}

Staphylococcus aureus adalah bakteri Gram positif yang tidak menghasilkan spora dan tidak motil, umumnya tumbuh berpasangan maupun berkelompok, dengan diameter sekitar 0,8 mikron 1,0 mikron. Bakteri Staphylococcus aureus ini tumbuh dengan suhu $37^{\circ} \mathrm{C}$ (Jumriani, 2017). Penelitian Ririn (2014) menunjukan bahwa pembentukan enterotoksin yang dihasilkan oleh Staphylococcus aureus didalam daging ayam dipengaruhi oleh berbagai faktor antara lain yaitu sifat dan komposisi substrat, suhu dan waktu, $\mathrm{pH}$, aktivitas air adanya garam $\mathrm{NaCl}$ dan nitrit, antibiotic dan sebagainya. Substrat yang baik untuk pertumbuhan sel dan produksi enterotoksin adalah substrat yang mengandung protein atau asam amino, garam anorganik dan vitamin. Gejala yang dialami pada saat keracunan akibat Staphylococcus aureus mual, muntah, kram perut dan diare serta terkadang disertai sakit kepala dan demam.

Berdasarkan hasil observasi di Pasar Besar Kota Palangka Raya, kondisi lingkungan tersebut masih kumuh dan sampah belum dikelola dengan 
baik. Penjualan daging ayam di pasar dijual dalam keadaan terbuka (tanpa penutup) begitupula yang kerapkali disajikan dalam bentuk bebas di meja tanpa adanya pengaturan suhu serta tidak memperdulikan aspek kebersihan produk tersebut . Personal hiegine dari penjual daging ayam tersebut masih kurang karena tidak terdapat tempat untuk mencuci tangan disekitar lokasi penjualan daging ayam. Tujuan penelitian mengetahui gambaran kontaminasi bakteri Staphylococcus aureus pada daging ayam yang dijual di Pasar Besar Kota Palangka Raya Tahun 2018. Bakteri ini pertama kali diamati dan dibiakkan oleh Pasteur dan Koch, kemudian diteliti lebih lanjut oleh Ogston dan Rosenbach pada tahun 1880-an. Namun genus Staphylococcus diberikan kepada Ogston karena jika diamati dengan mikroskop bakteri ini terlihat seperti setangkai buah anggur. Namun spesies aureus diberikan oleh Rosenbach karena pada biakan murni, koloni bakteri ini terlihat berwarna kuning-keemasan (Yuwono, 2012).

Bakteri Staphylococus aureus ini tumbuh pada suhu optimum $37^{\circ} \mathrm{C}$. Bakteri Staphlococccus aureus merupakan flora normal tumbuh pada kulit, saluran pernafasan, dan saluran pencernaan makanan pada manusia. Bakteri ini juga ditemukan di udara dan lingkungan sekitar. Staphylococcus aureus yang pathogen menghasilkan toksin bersifat invasif, menyebabkan hemolisis, membentuk koagulase dan mampu meragikan manitol. Bakteri mati pada saat terjadi proses pemanasan tetapi toksin yang dikeluarkan dapat bertahan. Klinis ditemukan andatanda peradangan setempat yang menyembuh setelah pus dikeluarkan. Dinding fibrin di sekitar abses dapat mencegah penyebaran kuman. Jika dinding ini rusak, kuman dapat menyebar sehingga terjadi bakteremia. Lokalisasi sekunder dalam suatu organ dapat menimbulkan tanda-tanda disfungsi dari organ yang bersangkutan dan tanda-tanda peradangan. Pada keracunan makanan karena enterotoksin, tidak ada gejala demam (Agus, 2010).

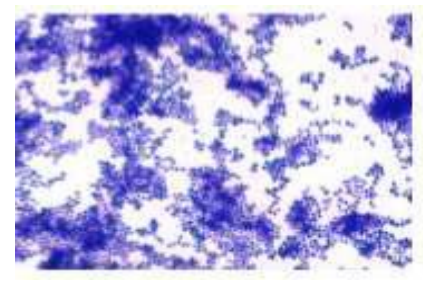

GAMBAR 1. Mikroskopik Pewarnaan Gram pada Sediaan

\section{METODE PENELITIAN}

\begin{tabular}{llr}
\multicolumn{2}{c}{ Penelitian ini menggunakan } & metode \\
observational & pendekatan deskriftif & untuk \\
mengetahui & gambaran kontaminasi & bakteri
\end{tabular} Staphylococcus aureus pada daging ayam yang dijual di Pasar Besar Kota Palangka Raya Tahun 2018. Waktu penelitian ini dilakukan pada bulan Maret Juni tahun 2018. Pengambilan sampel dilakukan di Pasar Besar Kota Palangka Raya dan Pemeriksaan Identifikasi Bakter Staphylococcus aureus dilakukan di laboratorim Mikrobiologi Fakultas Ilmu Kesehatan Universitas Muhammadiyah Palangkaraya. Populasi penelitian yang digunakan adalah daging ayam yang dijual di Pasar Besar Tradisional Kota Palangka Raya Tahun 2018. Sampel diambil pada 15 penjual daging ayam di Pasar Besar Kota Palangka Raya di Jalan Jawa dengan besar sampel yang diambil yaitu 1 gr/daging sesuai dengan SNI 7388:2009. Pengambilan sampel dilakukan pada seluruh penjual daging ayam di Jalan Jawa 2 kali pada hari yang berbeda.

Adapun teknik pengumpulan data yang digunakan adalah sebagai berikut: Observasi adalah teknik pengumpulan data secara observasi yaitu dengan melakukan pengamatan langsung di Pasar Besar Kota Palangka Raya Tahun 2018. Wawancara yang dilakukan berisi pertanyaan-pertanyaan untuk mengetahui karakteristik daging ayam meliputi sumber, lama waktu dan metode pengangkutan. Pemeriksaan pada media Manitol Salt Agar (MSA) Teknik analisis data pada identifikasi bakteri Staphylococcus aureus pada daging ayam di Pasar Besar Kota Palangka Raya menggunakan analisis univariate. Analisis univariate bertujuan untuk menjelaskan atau mendeskripikan karakteristik setiap variabel penelitian (Notoatmodjo,2014).

\section{HASIL DAN PEMBAHASAN}

Sampel yang diperiksa diambil sebanyak 1 gr/daging ayam yang diambil di Pasar Besar Kota Palangka Raya di sepanjang Jalan Jawa. Pengambilan sampel dilakukan pada tanggal 16 - 17 Mei 2018 yang dilakukan sebanyak dua kali. Pemeriksaan sampel ini dilakukan di Laboratorium Mikrobiologi Universitas Muhammadiyah Palangkaraya pada 
tanggal 16 - 23 Mei 2018. Sampel daging ayam setelah diambil tersebut ditimbang dan dimasukkan kedalam media BHI dan diinkubasi selama 24 jam pada suhu $37^{\circ} \mathrm{C}$ yang kemudian dilanjutkan pada media MSA dan pemeriksaan mikroskopis. dapun karakteristik sampel dapat dilihat pada tabel 1 . berikut.

TABEL 1. Karakteristik Daging Ayam Berdasarkan Sumber, Lama Waktu dan Metode Pengangkutan di Pasar Besar Kota Palangka Raya Tahun 2018

\begin{tabular}{|l|c|c|}
\hline \multirow{2}{*}{ Karakteristik } & \multicolumn{2}{c|}{ Frekuensi } \\
\cline { 2 - 3 } Sumber : & $\mathrm{n}$ & $\%$ \\
\hline a. Dalam Kota & 30 & 100 \\
\hline b. Luar Kota & 0 & 0 \\
\hline Total & $\mathbf{3 0}$ & $\mathbf{1 0 0}$ \\
\hline Waktu Penyajian: \\
\hline a. $>12$ jam & 0 & 0 \\
\hline b. 6-12 jam & 0 & 0 \\
\hline c. 3-6 jam & 12 & 40 \\
\hline d. $<1$ jam & 18 & 60 \\
\hline Total & $\mathbf{3 0}$ & $\mathbf{1 0 0}$ \\
\hline Pengemasan & 0 & 0 \\
\hline a. Kotak/Kardus & 0 & 0 \\
\hline b. Karung & 30 & 100 \\
\hline c. Kantong Plastik & $\mathbf{3 0}$ & $\mathbf{1 0 0}$ \\
\hline Total
\end{tabular}

TABEL 2. Gambaran Kontaminasi Bakteri Staphylococcus aureus pada daging ayam yang dijual di Pasar Besar Kota Palangka Raya Tahun 2018

\begin{tabular}{|c|c|c|}
\hline Kontaminasi & \multicolumn{2}{|c|}{ Frekuensi } \\
\cline { 2 - 3 } Staphylococcus aureus & $\mathrm{n}$ & $\%$ \\
\hline Positif & 5 & 16,7 \\
\hline Negatif & 25 & 83,3 \\
\hline Total & $\mathbf{3 0}$ & $\mathbf{1 0 0}$ \\
\hline
\end{tabular}

Hasil penelitian menunjukan bahwa $100 \%$ sampel positif pada media BHI. Selanjutnya pada media MSA ditemukan (Tabel 1.1) menunjukan bahwa 16,7\% sampel positif terkontaminasi Bakteri Staphylococcus aureus. Dimana sampel yang positif menunjukkan kesesuaian dengan kontrol positif Staphylococcus aureus, dengan ciri-ciri yaitu koloni cembung, berwarna kuning keemasan dan warna media berubah menjadi kuning. Sedangkan pada sampel negatif ditumbuhi bakteri kontrol negatif dan diluar ciri-ciri seperti kontrol positif.

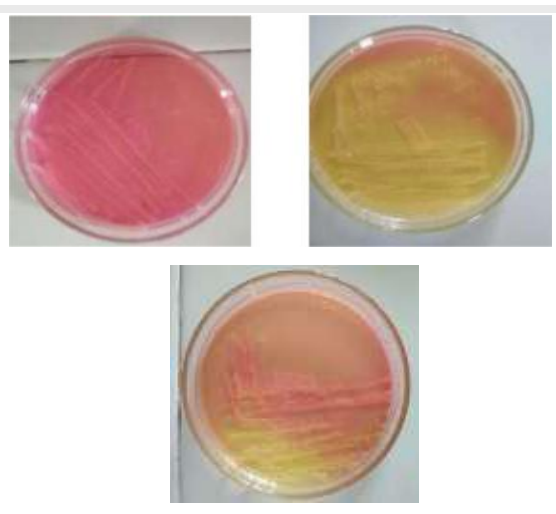

GAMBAR 2. Hasil pada media MSA, (a) pertumbuhan kontrol negatif bakteri Staphylococcus epidermidis,(b) pertumbuhan kontrol positif bakteri Staphylococcus aureus, (c) pertumbuhan bakteri dengan ciri-ciri Staphylococcus aureus

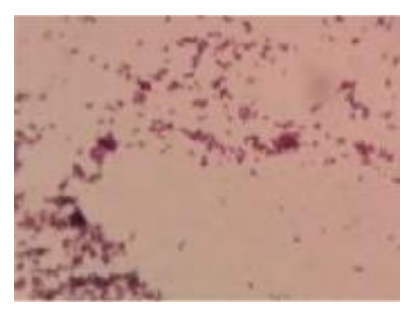

GAMBAR 3. Mikroskopis Sediaan Kontrol Positif Staphylococcus aureus

Penelitian Smita (2014) pada pasar tradisional kontaminasi bakteri Staphylococcus aureus dapat terjadi ketika proses pemotongan, pengeluaran jeroan, proses distribusi daging ayam mentah dari peternak ke pedagang, jika semakin jauh jarak pemotongan ke lokasi penjualan dengan pengangkutan tidak menggunakan pendingin maka memungkinkan terkontaminasi Staphylococcus aureus pada daging ayam (daging ayam dibawa pada suhu ruang sehingga menyebabkan Staphylococcus aureus dapat berkembangbiak dengan cepat pada daging). Selain sumber, hasil penelitian juga menunjukan $13,3 \%$ positif rata-rata lama waktu penyajian 3-6 jam pada sampel hari pertama. Penelitian Dwi (2017) semakin lama waktu pemotongan hingga penjualan semakin banyak pula pertumbuhan bakteri pada daging ayam karena diletakkan pada lokasi yang kurang higiene dan alas tempat meletakkan daging ayam yang masih tidak memadai. Tercemarnya bakteri Staphylococcus aureus pada daging ayam dapat dipengaruhi karena tempat berjualan daging ayam masih diletakkan di atas meja dengan alas yang tidak memadai sehingga 
mengakibatkan jumlah total bakteri yang tinggi pada daging ayam dan bakteri yang memang secara normal ada dalam tubuh hewan akan makin subur, sarana air bersih yang kurang baik, lokasi penjualan daging ayam di Pasar Rukoh masih bergabung dengan pedagang lainnya, kebersihan penjual yang kurang baik, serta cara pengemasan.

\section{KESIMPULAN}

Berdasarkan hasil penelitian identifikasi Staphylococcus aureus pada daging ayam yang dijual di Pasar Besar Kota Palangka Raya di sepanjang Jalan Jawa, ditemukan $16,7 \%$ sampel daging ayam teridentifikasi mengandung Staphylococcus aureus. Hal ini dimungkinkan dipengaruhi oleh faktor kepadatan pengunjung, personal hiegine dari pedagang dan lama penyajian.

\section{DAFTAR PUSTAKA}

Agus. 2010. Buku Ajar Mikrobiologi Kedokteran. Binarupa Aksara : Jakarta

Dwi. 2017. Jumlah Cemaran Escherichia coli Pada Daging Ayam Broiler Di Pasar Rukoh Banda Aceh. Skripsi ISSN, Banda Aceh

Ibrahim Jumriani. 2017. Tingkat Cemaran Bakteri Staphylococcus Aureus Pada Daging Ayam Yang Dijual Di Pasar Tradisional Makassar. Skripsi Fakultas Sains Dan Teknologi Universitas Islam Negeri Alauddin, Makassar

Ririn Puspadewi, Putranti Adirestuti,R ina Anugrah. 2014 . Kajian Kontaminasi Staphylococcus aureus pada Pangan. Skripsi Fakultas Farmasi Universitas Jenderal Achmad Yani, Solo

Soekidjo Notoatmodjo.2014.Metodologi Penelitian Kesehatan.. Rineka :Jakarta

Smita Siti Maulitasari. 2014. Identifikasi Cemaran Stahpylococcus aureus Pada Daging Ayam Yang Di Jual Di Pasar Tradisonal Dan Modern Di Sekitar Kampus Institut Pertanian Bogor. Skripsi Fakultas Kedokteran Hewan Institut Pertanian Bogor , Bogor
Yuwono. 2012. Staphylococcus aureus dan Methicilin-Resistant Staphylococcus aureus (MRSA). Skripsi Departemen Mikrobiologi FK Unsri , Palembang 